\title{
MEMBANGUN FIKIH YANG BERORIENTASI SOSIAL: Dialektika Fikih dengan Realitas Empirik Masyarakat
}

\section{Zubaedi}

Sekolah Tinggi Agama Islam Negeri Bengkulu

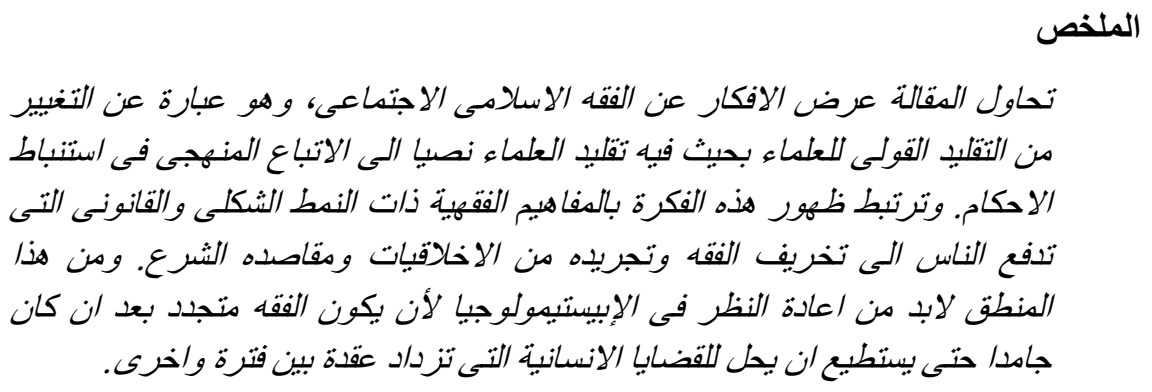

\section{Abstract}

The present article describes thoughts of what recently called as "social fiqh", which its substance is an attempt to change qawly paradigm (namely following the sayings of scholars) to manhajy paradigm (following the methodology of scholars). The rise of such idea much concerns with formalistic and legalistic trends of common classical fiqh. The formalistic and legalistic approach to figh has encouraged people to manipulate the figh and make it separated from ethics as its philosophical base. As the consequence, fiqh becomes rigid and looses its power to provide society with truly effective rules. An epistemological remedy is necessary to break down the rigidity of figh and make it powerful to solve social problem.

Keywords: fikih sosial, paradigma qawly, paradigma manbajy 


\section{A. Pendahuluan}

Fikih dalam perjalanan sejarah telah memberikan pengaruh yang sangat dominan dalam kehidupan umat Islam. Sayangnya, perkembangan fikih yang begitu mengesankan telah mengarahkannya menjadi salah satu cabang ilmu keislaman yang tekstualistik-formalistik. Para ahli fikih menjadi lebih sibuk memperhatikan kata-kata atau cenderung menggunakan pandangan secara harfiah. Dalam masalah pernikahan dan jual-beli misalnya, baru dipandang sah kalau mengucapkan lafallafal tertentu. Jika ada orang non-Arab melakukan pernikahan dengan menggunakan bahasanya sendiri, akadnya dianggap tidak sah kecuali menggunakan bahasa Arab. ${ }^{1}$

Fenomena keterpakuan tekstual ini membuat Imam al-Ghazali prihatin dan mengatakan, sesungguhnya para ahli fikih adalah ulamaulama dunia, sebab mereka mengabaikan niat, tujuan dan melupakan bahwa masalahnya adalah masalah agama yang ditujukan kepada Allah dan akhirat. Mereka hanya memperhatikan lafaz-lafaz dan persoalanpersoalan cabang yang terperinci. ${ }^{2}$

Bagi kalangan yang mengembangkan pola pikir tekstualis, maksud syara' hanya dapat diketahui dari lafal teks sebagaimana apa adanya

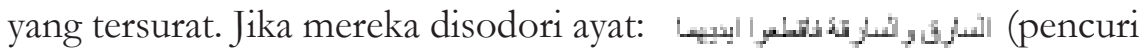
laki-laki atau perempuan maka potonglah kedua tangannya), ${ }^{3}$ maka akan menjawab, hukuman untuk pencuri tidak ada lain kecuali dipotong tangannya. Alasan yang mereka kemukakan adalah sesungguhnya maksud syari‘ (Tuhan) adalah misterius sebelum Dia (Tuhan) menjelaskan-nya sendiri. Hal ini tidak bisa terjadi kecuali melalui firman yang jelas dan tidak mengandung makna-makna lain. ${ }^{4}$ Karena mereka berpegang pada lahirnya teks, maka dalam menentukan hukum tidak memerlukan bantuan di luar naș. Sebagai konsekuensinya, mereka menolak maslahah mursalah, istihsan maupun qiyas dalam menentukan hukum. Mereka menerima ta'wil secara terbatas, yaitu ketika ada nas

${ }^{1}$ Hasan al-Turabi, , Fiqih Demokratis, terj. Abdul Haris dan Zainul Am, cet. 1, (Bandung: Arasy, 2003), hlm. 19.

${ }^{2}$ Ibid., hlm. 20.

${ }^{3}$ Al-Qur'an Surat al-Mā'idah ayat 38.

${ }^{4} \mathrm{Abū}$ Isḥāq Ibrāhim Ibn Mūsa al-Shātibi, al-Muñäfaqāt fi Ușül al-Sharì'ah, (Kairo: Muṣțafa Muḥammad, tth, II), hlm. 39. 
lain yang mengeluarkannya dari makna lahirnya (zăhir). Naș lain itu pun harus lahir (žăhir), baik berasal dari al-Qur'an maupun Hadis Nabi. ${ }^{5}$ Dengan demikian, zabir-nya suatu naș. hanya dapat dita'wil dengan nas lain yang berjenis lafal zaabir pula.

Bisa digarisbawahi bahwa kemunduran yang dialami oleh fikih Islam dewasa ini diduga kuat juga disebabkan oleh kurang relevannya perangkat teoritik ilmu ushul fikih untuk memecahkan problem kontemporer. Karya-karya di bidang ushul fikih baik baik al-Risälah karya al-Syafi'i, buku-buku ushul mazhab mutakallimun maupun mazhab Hanafiyyah memiliki kesamaan paradigma yaitu paradigma literalistik, dalam arti begitu dominannya pembahasan tentang teks berbahasa Arab baik dari segi grammar maupun sintaksisnya dan mengabaikan pembahasan tentang maksud dasar dari wahyu yang berada di balik teks literal. ${ }^{6}$

Metode literal (al-tariqah al-laf:ziyyah) ditujukan kepada teks-teks syari'ah yang berupa al-Qur'an dan Hadis untuk mengetahui bagaimana cara lafaz-lafaz kedua sumber itu menunjukkan kepada hukum-hukum fikih yang dimaksudkannya. Dengan meminjam kerangka analisis alJabiry, model berpikir yang memusatkan pada kajian teks dan bahasa pada umumnya dikategorikan sebagai corak berpikir yang menggunakan epistimologi bayāny, yang berbeda secara tegas dari model berpikir dan berijtihad model burhāny dan lebih-lebih 'irfany.?

Disiplin ilmu hukum Islam (fikih) bersama-sama dengan ilmu bahasa Arab dan Ilmu Kalam pada dasarnya berpijak pada nalar bayāny karena berlandaskan pada otoritas teks. Mayoritas ahli hukum Islam dalam sepanjang sejarahnya memang telah menggunakan nalar bayāny sebagai landasan berpikirnya. ${ }^{8}$ Al-Qur'an dan as-Sunnah yang menjadi

${ }^{5}$ Abū Muhammad Ali ibn Aḥmad ibn Sa’id ibnu Ḥazm, al-Aḅkām fi Ușūl alAḥkām, (Mesir: al- 'Așimat, t.t, I), hlm. 42.

${ }^{6} \mathrm{M}$. Amin Abdullah, Madžbab Yogya, Menggagas Paradigma Ushul Fiqh Kontemporer, (Yogyakarta: Arruz Press, 2002), hlm. 118.

${ }^{7}$ M. Amin Abdullah, "Al-Ta'wil al-'Tlmi: Kearah Perubahan Paradigma Penafsiran Kitab Suci”, Al-Jami'ah, (Yogyakarta: IAIN Sunan Kalijaga, 2001, Vol. 39), hlm. 359391.

${ }^{8}$ Muhammad 'Abid al-Jabiri, Bunyah al-Aq al-Araby: Dirāas Taḅhiliyyah Naqdiyyah li Nuz̄um al-Ma'rifah fi al-Saqāfah al-'Arabiyyah (Beirut: Markaz Dirāsat al- Wahdah al'Arabiyyah, 1990), hlm. 13-14. 
sumber hukum Islam merupakan teks yang berbahasa Arab sehingga seliberal apa pun pemikiran hukum Islam tidak akan bisa sama sekali lepas dari teks. Oleh karena itu, pemikiran hukum Islam yang memiliki kecenderungan rasional-filosofis pada dasarnya hanya meminjam nalar burbāny, sebagai dasar pijakan untuk menganalisis maksud teks al-Qur'an dan as-Sunnah sebagai sumber hukum Islam. Atas dasar ini al-Jabiri menyebut kecenderungan pemikiran rasional-filosofis dalam hukum Islam seperti ini dengan istilah ta'sis al-bayān 'alā al-burbān (membangun disiplin ilmu bayāny) dalam hukum Islam dengan dasar pijakan kerangka burhāny.

Jika dilacak secara historis, latar belakang terpuruknya fikih pada keterpakuan tekstual tidak terlepas fenomena perpecahan di kalangan umat Islam. Kondisi keterpurukan fikih pada saat itu bisa dilukiskan sebagai berikut:

Kondisi rapuh bangsa-bangsa muslim yang berlangsung sejak pertengahan abad ke-14 sampai jatuhnya Baghdad membawa akibat pula pada rapuhnya kondisi fiqh. Akibatnya tertutuplah pintu ijtihad dan terbelenggunya akal pikiran. Ini merupakan akibat logis dari hilangnya kebebasan berpikir dan kesibukan masyarakat dalam kehidupan yang materialistis. Berkembanglah kemudian semangat taqlid di kalangan fuqaha, di mana untuk menghadapi berbagai masalah dan kasus hukum, mereka tidak lagi menggunakan daya pikir melainkan lebih banyak mengikat diri pada pendapat-pendapat para ulama pendahulunya. ${ }^{9}$

Persoalannya lalu berkembang sedemikian rupa sehingga fukaha memandang pendapat-pendapat para imam mazhab sebagai nas-nas (teks-teks) yang tidak dapat diubah, digugat dan diganti. Mereka memandang teks-teks mazhab sebagai syari'at sehingga nas-nas alQur'an dan Sunnah harus disesuaikan dengan mazhabnya. Dalam waktu bersamaan kegiatan-kegiatan dalam bidang fikih ditangani oleh para hakim (qädi) yang kurang memiliki keahlian ilmiah secara memadai. Mereka mencukupkan diri dengan menghafal hukum-hukum mazhab yang menjadi pedoman pengadilan tanpa harus berpikir dan berijtihad atau melakukan pembaharuan di bidang hukum. Mereka cukup

${ }^{9}$ Farouk Abu Zaid, Hukum Islam: antara Tradisionalis dan Modernis, terj. Husein Muhammad, , cet. 1, (Jakarta: P3M, 1986), hlm. 48-49. 
menerapkan sepenuhnya hukum-hukum yang dihasilkan para imamnya tanpa melakukan apa pun. ${ }^{10}$

Hilangnya semangat ilmiah ini, pada sisi lain, mengakibatkan keterpakuan tekstual. Periwayatan pendapat-pendapat para imam tanpa melalui verifikasi ilmiah yang memadai telah menimbulkan keanekaragaman pendapat imam dalam satu persoalan. Keadaan fikih yang memburuk demikian menjadi pertimbangan para fukaha untuk sepakat mengeluarkan fatwa bahwa pintu ijtihad telah tertutup. Berkaitan dengan penutupan pintu ijtihad, Anderson menyatakan: ${ }^{11}$ "dengan mengkristalnya ajaran mazhab, hak berijtihad hanya dibatasi sampai kira-kira akhir abad ke-3 H yang ditandai dengan diterimanya jargon "pintu ijtihad telah ditutup". ${ }^{12}$

Munculnya gerakan penutupan pintu ijtihad justeru membawa suatu bencana yaitu mengakarnya taqlid di kalangan umat. Keadaan ini juga memaksa para fukaha untuk mengambil pendapat para imam masa lalu secara penuh terutama para imam mazhab empat. Mereka lupa mempertimbangkan faktor perbedaan zaman dan keadaan masyarakat serta persoalan yang dihadapi. Adalah wajar jika ikrar tertutupnya pintu ijtihad telah mengakibatkan semakin beku dan statisnya fikih. ${ }^{13}$

Bersamaan dengan itu, muncullah problem kesenjangan dalam fikih yaitu bagaimana fikih yang dipahami secara tekstual dan kaku menjawab berbagai persoalan yang terus berkembang. Ada beberapa hal yang menyebabkan adanya jarak (baca: kesenjangan) antara fikih secara teoritis dengan kenyataan sosial yang praktis. Pertama, kekaguman yang berlebihan dari para ulama kepada para imam dan guru. Kedua, munculnya gerakan kodifikasi fikih para imam. Ketiga,

\footnotetext{
${ }^{10}$ Mun'in A Sirry, Sejarah Fiqib Islam: Sebuab Pengantar, (Surabaya, Risalah Gusti, 1995), hlm. 129.

${ }^{11} \mathrm{~J}$. N. D Anderson, Law Reform in The Muslim World, (London: The Athlone Press, 1976), hlm. 7.

${ }^{12}$ Pendapat yang menyatakan pintu ijtihad tertutup sehabis masa imam mazhab empat disampaikan oleh sebagian ulama dari kaum Hasyawiyyah. Baca Muhammad Salām Maẓuūr, al-Ijtihād fi al- Tashri' al- Islāmy, (Kairo, Dār al- Nahḍah al-'Arabiyyah, 1974) hlm. 174.

${ }^{13}$ Farouk Abu Zaid, Hukum Islam: antara Tradisionalis dan Modernis, hlm. 50.
} 
penggunaan mazhab tertentu dalam pengadilan. Keadaan di atas menyebabkan para ahli fikih sudah merasa puas dengan usaha membuat ikhtisar karya-karya ulama masa lalu. Mereka sudah merasa puas mengembalikan segalanya pada ringkasan-ringkasan (mukbtasar) atau teks-teks (mutün) dan komentar-komentar (sharḥ). Mereka tidak lagi berusaha sungguh-sungguh untuk kembali kepada hukum-hukum asli para imam mereka. ${ }^{14}$

\section{B. Tuntutan Pengembangan Fikih Sosial}

Masyarakat pada dasarnya berwatak dinamis dan tidak berkarakter statis. Oleh karena itu, apa yang disebut perubahan sosial (social change), kapan dan di mana pun akan selalu terjadi dalam setiap kehidupan. Sebagai implikasinya, setiap perubahan sosial baik cepat atau lambat selalu menuntut perubahan dan pembaharuan dalam berbagai bidang termasuk di dalamnya bidang hukum dan perundangundangan yang merupakan salah institusi penting bagi kehidupan manusia.

Tanpa kecuali, fikih atau hukum-hukum fiqhiyyah perlu bersifat responsif terhadap perubahan dan perlu mengakomodasikan berbagai perubahan konteks sosial-budaya yang terjadi. Fikih, yang disebutsebut memiliki daya elastis memberikan ruang gerak yang memadai bagi kemungkinan terjadinya perubahan hukum dari waktu ke waktu dan tempat ke tempat. Ungkapan berikut mengisyaratkan hal itu: "Berubah dan berbedaannya fatwa itu sejalan dengan perubahan zaman, tempat, kondisi sosial, niat, dan adat kebiasaan yang berlaku". ${ }^{15}$

\section{Relevansi Fikih dengan Realitas Sosial}

Diakui atau tidak, fikih yang tersedia saat ini mempunyai sejumlah problematika, antara lain: mapannya paradigma klasik dan lambannya upaya pembaharuan sehingga dengan mudah didapatkan adanya pengulangan-pengulangan yang tidak perlu, yang pada akhirnya menyebabkan terjadinya kesenjangan antara fikih dengan realitas. ${ }^{16}$

${ }^{14}$ Ibid, hlm. 52.

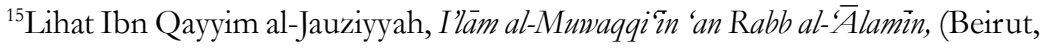
Dār al-Kutub al-'Ilmiyyah, 1996), Juz 3, hlm. 11.

${ }^{16}$ Mun'in A Sirry, Sejarah Fiqih Islam, Sebuah Penganta... hlm. 3. 
Problematika itu perlu diatasi agar fikih sebagai proses ijtihadi dan dialektika antara doktrin dan realitas dapat bersuara kembali atas zaman yang secara kontekstual berbeda dengan zaman di mana fikih dikodifikasikan. Di sinilah letak urgensinya dimunculkan perspektif baru terhadap fikih yang mengamodasikan arus perubahan dan berbagai realitas sosial yang muncul di era modern. Realitas sosial perlu diakomodasikan oleh fikih, sesuai dengan saran Ibn Taimiyyah bahwa masalah-masalah riil yang berhubungan dengan umat Islam sehari-hari itulah yang diperhatikan, bukan masalah skolastik yang bersifat formalistis. ${ }^{17}$

Upaya memunculkan perspektif baru dalam berfikih merupakan bagian dari apreasiasi terhadap peninggalan fukaha masa lalu. Hal ini karena penghargaan umat terhadap karya fukaha masa lalu seharusnya bukan dalam bentuk pelestarian keutuhan formulanya sebagaimana adanya tetapi justeru pada pengembangannya secara kreatif, dinamis, dan konstruktif. Kini, umat Islam, terutama para ulama dan pakarnya dituntut merumuskan teori serta formula hukum yang kontekstualresponsif sejalan dengan perkembangan sosial budaya yang terus meminta paradigma baru.

Sikap akomodatif hukum Islam terhadap perubahan sosial sesuai dengan ungkapan: لاينكر تثيز الاحكام بتغيز الازمان والأكان (tidak diingkari terjadinya perubahan hukum disebabkan berubahnya waktu dan tempat). Kaidah ini membawa konsekuensi, suatu kewajaran untuk mengganti hukum Islam disesuaikan dengan perubahan masa dan pengaruh dari lingkungan masyarakat. ${ }^{18}$ Sifat adaptif ini perlu melekat dalam proses ijtihad hukum Islam karena realita yang ada seringkali menunjukkan bahwa perkembangan masyarakat dan pendapat umum berjalan lebih dinamis dan lebih cepat daripada perkembangan hukum itu sendiri. ${ }^{19}$

${ }^{17}$ Muhammad Amin, Ijtihad Ibn Taimiyyah dalam Bidang Fikih Islam, (Jakarta: INIS, 1991), hlm. 27.

${ }^{18}$ Aḥmad al-Zarqa', Sharḥ al-Qawä id al-Fiqhiyyah, (t.t.p: Dār Gharb al-Islāmy, 1983), hlm. 173.

${ }^{19}$ Subhi Mahmassani, Falsafah al-Tashri’' fi al-Islām, (Beirut: Dār al-'Ilmi, 1961), hlm. 220. 
Zubaedi

Ibn Qayyim al-Jauziyyah dalam konteks ini bisa dijadikan dasar dalam menjustifikasi adanya perubahan hukum Islam. Ia membela perubahan fatwa dikarenakan adanya perubahan waktu, tempat dan suasana. Pendapat ini didasarkan pada riwayat yang diperoleh dari gurunya, Ibnu Taimiyyah, yang mengatakan sebagai berikut:

Pada suatu hari di zaman Tartar, saya bersama beberapa orang sahabat berpapasan dengan kelompok pasukan Tartar yang sedang meneguk alkohol. Salah seorang sahabat ingin menegur mereka, tetapi saya cegah dengan mengatakan bahwa Allah telah melarang minuman keras karena minuman ini bisa menyebabkan mereka melupakan Tuhan dan salat, tetapi minuman keras di sini membelokkan mereka dari membunuh, menculik anak-anak maupun merampok barang-barang. Meneguk minuman keras di sini dilupakan bukan dalam kaitan dengan kepentingan umum tetapi dalam kaitan dengan kebutuhan mendesak untuk mengamankan masyarakat dari pembunuhan dan perampokan. ${ }^{20}$

\section{Fikih Sebenarnya Berdimensi Sosial}

Fikih Islam adalah fikih yang hidup dan berkembang, yang akan bergumul dengan persoalan-persoalan kekinian yang senantiasa meminta etik dan paradigma baru. Keluasan kekayaan fikih adalah salah satu bukti dari ruang gerak dinamis itu. Ia merupakan implementasi objektif dari doktrin Islam yang meskipun berdiri di atas kebenaran mutlak dan kokoh, juga memiliki ruang gerak dinamis bagi perkembangan, pembaharuan dan kehidupan sesuai dengan fleksibilitas ruang dan waktu. Bagi orang yang mempelajari berbagai ikhtilaf, ketegangan-ketegangan bahkan konflik yang mengiringi munculnya mazhab-mazhab fikih akan mengetahui bahwa semua itu merujuk pada perbedaan tempat, waktu, situasi dan sosial budaya di mana hukum itu tumbuh. Berkaitan dengan hal ini, Ahmad Hasan mengatakan:

Tampaknya Nabi memberikan ruang yang luas bagi (adanya kemungkinan) ikhtilaf dengan memberikan perintah yang bersifat umum atau dengan membenarkan dua bentuk yang berbeda dalam situasi yang sama. Sejak awal, Nabi sangat menekankan untuk memberikan

${ }^{20}$ Ibid., hlm. 117

${ }^{21}$ Ahmad Hasan, The Early Development of Islamic Jurisprudence, (Islamabad: Islamic Research Institute, 1970), hlm. 13. 
kesempatan bagi penggunaan akal pikiran dan kaidah-kaidah umum dalam berbagai situasi". ${ }^{21}$

\section{Prinsip-prinsip Fikih Sosial}

Menurut Ibnu Taimiyyah, tujuan utama dan pertama dengan kehadiran syari'ah ialah untuk mewujudkan kemaslahatan sesempurna mungkin dan menolak total mafsadah atau paling tidak menekannya seminimal mungkin. ${ }^{22}$ Tujuan utama syari'ah untuk merealisasikan kemaslahatan umum (li tạ̣qiq al-masalih al-'ammah) didasarkan pada

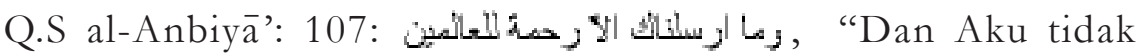
mengutus engkau (Muhammad) melainkan sebagai rahmat bagi seluruh alam."23

Fikih sebagai formulasi pemahaman terhadap syari'ah memiliki dua tujuan. Pertama, untuk membangun perilaku setiap individu muslim berdasarkan akidah, syari'ah, dan akhlak. Kedua, dapat merealisasikan sebuah tatanan kehidupan sosial masyarakat yang memiliki jati diri keadilan, persamaan dan kemitraan. ${ }^{24}$

Persoalannya mengapa fikih yang watak dasarnya bersifat responsif, kontekstual, dan sosial dalam perkembangan cenderung menjadi pasif, formalistik, dan individualistik. Munculnya fenomena ini diduga sebagai akibat dari keterbatasan kekayaan atau sumber bacaan (reference) para ahli fikih dalam satu ragam mazhab. Keterbatasan dalam penguasaan khasanah keilmuan fikih pada gilirannya membawa dampak terhadap munculnya pemahaman tunggal terhadap satu mazhab. Mereka menjadi kurang responsif terhadap pemikiran mazhab yang lain dan berbagai problem masyarakat sekelilingnya.

Dalam konteks mencari jalan keluar untuk membongkar kejumudan fikih selama ini, maka upaya pemahaman dan pemaknaan fikih secara kontekstual menjadi sangat penting untuk dilakukan. Dari sini, pendekatan etis dengan berorientasi esoterik (sufistik) yang

22‘Abd Raḥman Ibn Muḥammad Ibn Qāsim al-'Așimi, Majmū‘ Fatawā Shaykh Islām Aḥmad ibn Taymiyya, (t.t: t.p,), t.t.p, Juz 20, hlm. 20. hlm. 508.

${ }^{23}$ Departemen Agama RI, Al-Qur'an dan Terjemahnya, (Jakarta : Depag RI, 1985),

${ }^{24}$ Ahmad Rafiq, Fiqh Kontekstual, dari Normatif ke Pemaknaan Sosial, cet. I (Yogyakarta: Pustaka Pelajar, 2004), hlm. 5. 
bermuara pada rüḥ tashrï' atau maqäsid al-shari' ah menjadi agenda penting untuk dilakukan dalam rangka mereformulasikan substansi dan tujuan fikih.

Oleh karena itu, menjadi tugas penting dan mendesak yang tidak bisa dihindari adalah melakukan pemahaman yang lebih kontekstual terhadap kitab-kitab fikih yang telah ditulis para ulama pada abad III dan IV H agar tidak kehilangan perannya menjadi rambu bagi kehidupan masyarakat. Untuk kepentingan ini, diperlukan keberanian dalam melakukan pembaharuan, sekurang-kurangnya reformulasi hukum dan tidak mentolerir adanya kevakuman hukum (dinyatakan mawquf), dengan dalih ulama terdahulu tidak membicarakannya.

Alternatif yang mungkin dapat ditempuh adalah "menghidupkan" kembali tradisi berpikir manhajy (metodologis) dengan mengakomodasi berbagai manhaj yang telah dirumuskan para ulama mazhab Sunni, seperti qiyās, istiḥsan, mașlahah mursalah, dan sadd alzari'ah secara simultan. Pendek kata, perlu memperkaya tradisi bermazhab secara qawly dengan bermazhab secara manhajy. Dengan kata lain, perlu melengkapi pendekatan tekstual yang sudah sangat terkenal di sebagian besar umat Islam dengan pendekatan kontekstual yang di dalamnya perlu mempertimbangkan dan mengakomodasikan dimensi kemaslahatan dan kebutuhan riil masyarakat.

Fikih dan usul fikih idealnya terus berkembang dalam menghadapi tantangan realitas kehidupan modern. Hasan Turabi menyebut sejumlah alasan bagi perlunya pembaruan usul fikih. Misalnya, menurutnya, produk-produk usul fikih dalam tradisi pemikiran fikih klasik masih bersifat sangat abstrak dan berupa wacana teoritis yang tidak mampu melahirkan pemahaman komprehensif dan justru melahirkan perdebatan yang tak kunjung selesai. Turabi juga berkesimpulan, fikih saat ini lebih berorientasi pada ijtihad dalam persoalan ibadah ritual dan masalah kekeluargaan, sementara persoalan hukum, ekonomi, hubungan luar negeri, dan sebagainya belum memiliki tempat yang semestinya dalam kajian fikih ${ }^{25}$.

Konteks di masa lalu dengan masa kini dan masa yang akan datang tentu saja berbeda. Masyarakat modern mempu-nyai logika dan

${ }^{25}$ Hasan al-Turabi, Fiqih Demokratis, hlm. 50-58. 
sikap yang jauh berbeda dengan apa yang dihadapi masyarakat Arab di zaman dulu. Mungkin juga letak geografis di mana Islam diturunkan dengan letak geografis In-donesia dan beberapa negara Asia lainnya memberikan inspirasi bagi lahirnya sebuah tafsir baru terhadap doktrin dan dogma keagamaan.

Perbedaan konteks dan sejarah inilah yang menyebabkan perlunya pembacaan yang bersifat distingtif antara syari'ah dan maqāsid al-Shari'ah. Selama ini ada upaya untuk menguniver-salisasikan syariat untuk semua zaman dan tempat. Apa yang diproduk ulama di masa lalu dianggap sebagai solusi bagi problem kemanusiaan kontemporer. Ini bukan tanpa konsekuensi. Akibatnya, syariat sebagai pranata nilai yang komprehensif menyangkut hubungan antara manusia dengan Tuhan (ibadah maḥdah) dan hubungan manusia dengan manusia dan makhluk lainnya (mu'amalah), mengalami kemandulan. Konsekuensinya, yang tampak ke permukaan adalah wajah fikih yang keras, kaku, dan rigid. Fikih sebagai cara mengambil kesimpulan sebuah hukum yang berasal dari sumber asli agama (al-Qur'an dan Hadis) pada akhirnya juga menjadi sangat teosentris, karena fikih lebih dianggap sebagai otoritas pengetahuan daripada upaya memfungsionalkan doktrin keagamaan untuk menyelesaikan ketegangan yang terjadi dalam realitas sehari-hari. Yūsuf al-Qaraḍawi melihat kenyataan mandulnya fikih ini ditandai dengan sistematisasi fikih yang dimulai dengan pembahasan mengenai ibadah. Menurutnya, karakteristik fikiih seperti ini telah memandulkan cara pandang fiqh terhadap masalah-masalah sosial, politik dan ekonomi.

Karenanya, Qaraḍawi mengajukan alternatif pemikiran agar fikih direformasi menjadi fikih realitas (fiqh al-waqqi') dan fikih prioritas (fiqh al-awlawiyyat), yaitu fikih yang dapat dijadikan sinaran baru bagi problem kemanusiaan yang muncul di tengah-tengah masyarakat. Dalam hal ini, syariat diharapkan tidak lagi hanya bercorak vertikalistik, yang hanya mengupas masalah hubungan manusia dengan Tuhan, melainkan mencoba merambah masalah-masalah kemanusiaan. Fikih didesak untuk menyentuh isu-isu kesetaraan gender (fiqh al-mar'ah), ketatanegaraan (fiqh al-daulah), kewarganegaraan (fiqh al--muwatanah) dan lain-lain. Di sini semakin terlihat bahwa mendinamisasikan fikih merupakan langkah awal guna mendekonstruksi syariat dari wajahnya 
yang statis, eksklusif, dan diskriminatif menjadi syariat yang dinamis, inklusif, dan egalitarianistik.

Yūsuf al-Qaradawi merumuskan fiqh al-wäqi' (fikih realitas) dalam upayanya melakukan pembaruan fikih untuk menyikapi realitas modern. Al-Qaraḍawi menjelaskan, fiqh al-wäqi ialah pengetahuan mengenai realitas yang sebenarnya, baik yang menguntungkan maupun yang merugikan. Realitas ini penting dipahami karena pemahaman atas realitas akan menjadi pertimbangan tentang bagaimana berhubungan dengan realitas: apakah realitas itu akan diterima atau ditolak. ${ }^{26}$

Atas dasar ini, fiqh al-wäqi' yang digagas al-Qaraḍawi menggunakan pendekatan burbāny yaitu pendekatan yang berpegang pada kekuatan natural manusia berupa indera dan otoritas akal dalam memperoleh pemahaman atau pengetahuan. ${ }^{27}$ Burbäny atau pendekatan rasional argumentatif adalah pendekatan yang mendasarkan diri pada kekuatan rasio melalui instrumen logika (induksi, deduksi, abduksi, simbolik, proses dan lain-lain) dan metode diskursif (baḥsiyyah). Pendekatan ini menjadikan realitas maupun teks dan hubungan antara keduanya sebagai sumber kajian. Dalam pendekatan ini, teks dan realitas (konteks) berada dalam satu wilayah yang saling mempengaruhi. ${ }^{28}$

Menurut al-Qaradawi, akan ditemukan hukum dalam Sirah Nabi saw yang tidak sama penerapannya dalam berbagai situasi yang terjadi karena perbedaan realitas yang melatarbelakanginya. Misalnya, sikap Nabi saw. yang keras terhadap Yahudi Banu Quraizah dengan sikap beliau yang lembut terhadap kaum musyrik Makkah saat Fath Makkah. Oleh karena itu, para ulama menetapkan, fatwa itu bisa berubah karena perubahan zaman, tempat, keadaan, dan adat-istiadat. ${ }^{29}$

Dalam pandangan Yūsuf al-Qaraḍawi, ada beberapa fakta yang melatar belakangi munculnya fiqh al-wäqi. Sejak tahun 50-an dan 60-

${ }^{26}$ Yūsuf al-Qaradawi, Fiqih Peradaban: Sunnah Sebagai Paradigma Imu Pengetabuan (Al-Sunnab: Masdaran li al-Ma'rifah wa al-Hadarab), terjemahan oleh Faizah Firdaus. (Surabaya: Dunia Ilmu, 1997), hlm. 292.

${ }^{27}$ Muhammad Abid al-Jabiri, Bunyah al-'Aql al-A raby, hlm. 383-384.

28 "Manhaj Tarjih dan Pengembangan Pemikiran Islam (Hasil Munas Tarjih di Jakarta, 5-7 Juli 2000)", Lampiran 2 dalam Jaih Mubarok, Metodologi Ijtihad Hukum Islam,cet. 1, (Yogyakarta : UII Press, 2002), hlm. 219.

${ }^{29}$ Yūsuf al-Qaraḍawi, Fiqib Peradaban: Sunnah sebagai Paradigma Ilmu...,hlm. 94. 
an, telah terjadi dua aliran paham yang tidak menguntungkan bagi upaya kebangkitan umat: pada satu sisi ada sikap berlebihan (ifrät), sedangkan pada sisi lain ada sikap meremehkan (tafrit). Sikap berlebihan, misalnya, tidak mengakui pendapat lain, keras, dan suka mengkafirkan. Sebaliknya, sikap meremehkan ialah sikap kaum liberal yang berfatwa tanpa landasan agama dan hanya mengikuti hawa nafsu. Karena itulah, perlu dihidupkan prinsip moderatisme (tawassut) yang berintikan dua prinsip: (1) berasaskan kemudahan (taysir) dan kabar gembira; (2) perpaduan salafiah dan pembaruan (tajdid). Maksud salafiah adalah mengikuti sumber pokok, yakni al-Quran dan as-Sunnah; sedangkan pembaruan, maksudnya, adalah menyatu dan mengikuti zaman, tidak jumud (beku) atau taklid buta. Dalam rangka pembaruan itu, digagaslah fiqh al-wāqi ${ }^{30}$

Yūsuf al-Qaraḍawi menjelaskan dalil-dalil syariat yang melandasi fatwanya. Selain berpegang dengan 4 (empat) dalil pokok (al-Quran, as-Sunnah, Ijmak Sahabat, dan Qiyas) dan berpegang dengan dalil alIstị̧sān dan al-Mașälị̣ al-Mursalah. Al-Qaraḍawi memegangi kaidah, "adanya perubahan fatwa berdasarkan berubahnya zaman, tempat, dan kondisi. Kaidah ini sangat diutamakan dan ditonjolkan oleh Yūsuf alQaraḍawi, bahkan secara khusus ia menjelaskanya dalam satu kitab tersendiri, 'Awämil as-Sä'ah wa al-Murünah fi ash-Shari'ah al-Islämiyyah (Keluasan dan Kelunesan Hukum Islam). ${ }^{31}$

Dengan landasan-landasan tersebut, al-Qaradawi membenarkan sistem demokrasi dan tidak dianggap bertentangan dengan Islam dan membolehkan bergabung dengan pemerintahan yang bukan Islam. ${ }^{32}$ Mengapa Islam dapat menerima demokrasi? Sebab, menurut alQaraḍawi, substansi demokrasi adalah suatu proses pemilihan yang melibatkan orang banyak untuk mengangkat seseorang (kandidat) yang berhak memimpin dan mengurus keadaan mereka. Ini, menurutnya, sejalan dengan Islam, dan bahkan, berasal dari Islam itu sendiri. Sebab, Islam menolak seseorang menjadi imam shalat yang tidak disukai

${ }^{30}$ Ibid, hlm. 313.

${ }^{31}$ Yūsuf al-Qaraḍawi, Figh Praktis Bagi Kehidupan Modern, terjemahan oleh Abdul Hayyi al-Kattani, (Jakarta: Gema Insani Press, 2003), hlm. 35-91.

${ }^{32}$ Yuusuf al-Qaradawi, Figh Daulah dalam Perspektif Al-Quran dan As-Sunnah, terjemahan oleh Kathur Suhardi, cet. 6, (Jakarta: Pustaka Al-Kautsar, 2000), hlm. 181. 
makmum. Jika dalam shalat saja demikian, apa lagi dalam urusan politik. Prinsip kedaulatan rakyat, kata al-Qaraḍawi tidak mesti dipertentangkan dengan kedaulatan Allah, selama tidak ada pertentangan di antara keduanya. ${ }^{33}$

Bolehnya bergabung dengan pemerintahan bukan Islam, menurut al-Qaradawi, hukum dasarnya sebenarnya tidak boleh. Akan tetapi, al-Qaraḍawi lalu bersikap keluar dari hukum dasar ini dan kemudian membolehkannya dengan syarat-syarat tertentu. Alasannya: (1) tuntutan meminimalkan kejahatan dan kezaliman sesuai kesanggupan; (2) hal itu dilakukan untuk memilih kemadaratan yang paling ringan; (3) karena melepaskan nilai tertinggi lalu turun ke realitas terendah; (4) ada prinsip pentahapan (tadarru) $)^{34}$

Langkah kolosal yang dilakukan ulama kontemporer dalam rangka memperbaharui fikih pada intinya ditujukan untuk menempatkan syariat sebagai sumber nilai dan etika sosial, bukan hanya sekadar sumber hukum. Kendatipun tidak bisa dipungkiri, bahwa syariat juga mengatur hal-hal yang bersifat taken for granted, tapi meletakkan syariat hanya dalam kerangka sumber hukum dapat menyebabkan hilangnya kelenturan syariat. Akibatnya, syariat rentan pada monopoli tafsir untuk kepentingan kekuasaan.

Untuk itu, yang mesti diangkat ke permukaan adalah syari'at dalam arti sebagai sumber kemaslahatan. Kemaslahatan yang dimaksud tidak hanya kemaslahatan untuk Tuhan dan penguasa an-sich, melainkan kemaslahatan bagi manusia di seantero alam. Karenanya, yang perlu dikedepankan adalah fiqh al-maqāsid, yaitu fikih yang lebih mengutamakan nilai-nilai kemanusiaan seperti kemas-lahatan, keadilan dan kesetaraan daripada hukum-hukum yang bersifat partikular. Untuk keperluan ini, sangat mengandaikan perlunya pemahaman yang melihat Islam sebagai sumber etik sekaligus sumber alternatif baru. Jadi, seorang fukaha perlu memahami bahwa dibalik teks terdapat moralitas dan etika sosial yang mendasari kelahiran teks. ${ }^{35}$

${ }^{33}$ Yūsuf al-Qaraḍawi, Fiqh Daulah dalam Perspektif , hlm. 197.

${ }^{34}$ Ibid, hlm. 249-260.

${ }^{35}$ Zuhairi Misrawi dan Novriantoni, Doktrin Islam Progresif, Memahami Islam Sebagai Ajaran Rahmat,cet. 1, (Jakarta: LSIP, 2004), hlm. 29. 
Para ulama klasik menyebut fiqh al-maqāsid sebagai ilmu yang mendasari kelahiran fikih ('ilm usül al-fiqh). Sejak kelahirannya pertama kali oleh al-Syafici dalam karya besarnya, al-Risälah, figh al-maqāsid ini kurang mendapat perhatian dari pemerhati masalah keagamaan. Dalam kurun waktu yang cukup lama, Syariat hanya dilihat dalam bentuk-bentuk hukum-hukum partikular (furu'). Konsekuensinva, ilmu yang mendasari kelahiran fikih tidak banyak tersentuh. Syariat dan fikih yang dianut lebih sekadar upaya mengejawantahkan kesimpulan-kesimpulan hukum yang diproduksi para ulama atau mazhab yang berkembang di masa lalu.

Karenanya, yang diperlukan saat ini adalah upaya menguak kembali hakikat doktrin keagamaan, terutama mengembalikan syariah pada al-maqāsid al-shari'ah, memulangkah fiqh pada usül fiqh, sehingga syariat dapat menegosiasikan visinya dengan kekinian dan kemodernan. Bukan hanya itu, syariat diharapkan dapat memotret konteks, ruang, dan zamannya.

Di antara ulama klasik yang sangat menonjol dalam mengembangkan fiqh maqasid adalah Abu Ishaq al-Syatibi. (790 H). Munculnya teori al-Syatibi didorong oleh sebuah keinginan yang kuat untuk menciptakan sebuah perangkat teoritis yang dapat meningkatkan fleksibilitas dan adaptabilitas hukum Islam. ${ }^{36}$ Al-Syatibi memberikan kontribusi secara signifikan dalam memperlakukan konsep maṣlahah sebagai suatu prinsip independen dalam teori hukum. Ia menggunakan metode pembuktian induktif yang berasal dari berbagai sumber dari al-Qur'an dan Sunnah hingga ijmak, qiyas dan bukti-bukti kontekstual. Ketika sejumlah dalil digabungkan untuk mengklarifikasi sebuah persoalan atau prinsip, pengetahuan akan persoalan atau prinsip itu akan menyatu dalam pikiran manusia dan menjadikannya sebuah keyakinan. Hal ini disebabkan kumpulan dalil-dalil tersebut memiliki efek terhadap pembuktian induktif yang lengkap. Sebagai contoh, lima hal mendasar yang harus dijaga yaitu: hak hidup, kekayaan, keturunan, akal, dan agama tidak ditemukan dalil naqli-nya secara tegas baik dalam

${ }^{36}$ Wael B Hallaq, A History of Islamic Legal Theories (Sejarah Teori Hukum Islam), Terj. E. Kusnadiningrat dan Abdul Haris bin Wahid, cet. 1, (Jakarta: Rajawali, 2001), hlm. 240. 
al-Qur'an dan Sunnah. Akan tetapi, pengetahuan akan hak universal ini ada dalam benak umat Islam baik sebagai masyarakat maupun individu. Keyakinan ini disebabkan oleh adanya fakta bahwa prinsipprinsip tersebut didukung oleh beragam dalil, yang jika disimpulkan secara keseluruhan mengarah kepada kepastian (qat.i), meskipun jika dalil itu dianalisis sendiri-sendiri tidak lebih merupakan dalil yang zanny. ${ }^{37}$

Secara umum para eksponen pembaharuan hukum Islam menggariskan bahwa pada prinsipnya fikih harus dekat dengan problemproblem kemanusiaan. Hal ini berarti fikih harus bersifat humanis atau fikih perlu berorientasi pada segi kemanusiaan atau memihak pada sisi-sisi kemanusiaan. Setiap hukum yang ditetapkan Allah haruslah dipahami dalam kerangka kemanusiaan. Dengan cara ini fikih dapat dibumikan. Perubahan orientasi ini akan melahirkan hukum yang subjektif, individual, situasional, dan kondisional dengan semangat menuju kehendak ilahi. ${ }^{38}$

Semangat untuk mendekatkan fikih dengan realitas masyarakat telah mendasari kemunculan gagasan fikih sosial. Pada konteks ini, fikih sosial merupakan sebuah grand design pemikiran fikih yang menekankan upaya membumikan nilai-nilai fikih (klasik) secara holistik (teopassing) terutama implementasi ajaran-ajaran fikih yang berkaitan dengan dimensi sosial, relasi individu dengan individu, masyarakat dengan negara atau sebaliknya. ${ }^{39}$ Dengan demikian, dapat dirumuskan bahwa fikih sosial adalah formulasi kajian ulama atau fukaha tentang persoalan hukum yang bersifat praktis ('amaly) yang diambil dari dalil syar'i dan berorientasi kepada persoalan-persoalan sosial kemasyarakatan. ${ }^{40}$

Fikih sosial digagas, dikembangkan, dan diarahkan untuk mendukung universalitas Islam sebagai petunjuk bagi manusia menuju kesalehan individual dan kesalehan sosial. Kesalehan individual lebih

\footnotetext{
${ }^{37}$ Wael B Hallaq, A History of Islamic Legal Theories, hlm. 245.

${ }^{38}$ Nadirsyah Hosen, "Pengantar Menuju Fiqh Humanis", Artikel diakses dari media.isnet.org. (Jakarta: Paramadina, 2004), hlm. 3.

${ }^{39}$ Mahsun Fuad, Hukum Islam Indonesia, dari Nalar Partisipatoris Hingga Emansipatoris,cet. 1, (Yogyakarta: LKiS, 2005), hlm. 4.

${ }^{40}$ Ahmad Rafiq, Fiqh Kontekstual, dari Normatif ke Pemaknaan Sosial, hlm. 8.
} 
berkaitan dengan persoalan praktek-praktek keagamaan dalam kehidupan sehari-hari, sementara kesalehan sosial berhubungan erat dengan masalah-masalah moralitas publik (public morality). Dalam wilayah kesalehan individual, fikih sebagai pemikiran Islam berupaya memberikan kontribusi berupa petunjuk-petunjuk praktis keagamaan (religious practical guidance), ibadah mabdab; dan masalah-masalah yang menyangkut moralitas pribadi (private morality). Sementara itu, dalam wilayah kesalehan sosial, fikih sebagai pemikiran Islam merespons wacana kontemporer, seperti masalah-masalah sosial-keagamaan, sosial budaya, sosial ekonomi, globalisasi dan lokalisasi, iptek, lingkungan hidup, etika dan rekayasa genetika serta bioteknologi, isu-isu keadilan hukum, ekonomi, demokratisasi, HAM, civil society, kekerasan sosial dan agama, gender, dan pluralisme agama, sekaligus merumuskan dan melaksanakan terapannya dalam praksis sosial. ${ }^{41}$

Pada dasarnya filosofi setiap ibadah adalah berdimensi ganda, yakni dimensi ḩabluminalläh dan ḩabluminannās. Artinya, setiap ibadah di samping akan membentuk terwujudnya kesalehan individual (spiritualitas individual - esoteris) tentunya akan membentuk terwujudnya kesalehan sosial (moralitas publik-eksoteris) sehingga termasuk ibadah salat tentunya juga memiliki dimensi ganda. Hal ini dapat dilihat dari maksud salat itu sendiri yang tertuang dalam al-Qur'an Surat al-'Ankabūt ayat 45, yakni: "Sesungguhnya salat itu mencegah perbuatan keji dan munkar". ${ }^{42}$ Dari ayat tersebut, mestinya jelas bahwa esensi ibadah salat adalah terwujudnya kesalehan sosial di samping terwujudnya kesalehan individual. Dalam bahasa agama, inilah yang disebut sebuah pencapaian pada hakikat ibadah.

Oleh karena itu, keliru manakala dalam menjalankan ibadah salat hanya berorientasi pada asal sah ibadahnya (habluminalläh). Orientasi semacam itu baru dalam mencapai kerangkanya saja, belum mencapai hakikatnya. Oleh karena itu, untuk mencapai hakikat ibadah salat, kiranya perlu mengaktualisasikan ibadah tersebut dalam dua dimensi

${ }^{41}$ PP Muhammadiyah, "Manhaj Pengembangan Pemikiran Islam”, lihat Internet Website http://www. geocities.com/tarjikh/Manhaj_tarjih/ operasionali sasi. htm, diakses pada 16 Februari 2006.

${ }^{42}$ Depag RI, Al-Qur'an dan Terjemahnya, (Jakarta: Depag RI, 1985), hlm. 637. 
sekaligus, yakni keabsahan ḅabluminalläh dan realisasi nilai ibadah dalam h.abluminannās. Jadi jelas, hakikat ibadah salat adalah berdimensi sosial ("salat" sosial). Inilah hakikat melaksanakan ibadah salat sebenarnya.

Konsep fiqh sosial dibangun di atas pemikiran bahwa kaum muslimin harus secara proporsional (non-dikotomik) dalam memperlakukan antara kewajiban individual dengan kewajiban sosial, antara ibadah yang bernilai individual dan ibadah yang bernilai sosial dan antara kesalehan individual dengan kesalehan sosial. Baik kewajiban individual maupun kewajiban sosial, ibadah bernilai individual maupun ibadah bernilai sosial serta kesalehan inidividual maupun kesalehan sosial memiliki kedudukan yang sama-sama penting untuk diperhatikan dalam rangka mencapai derajat keislaman yang paripurna. Hal ini sesuai dengan pesan yang dikandung oleh al-Quran Surat Āli 'Imrān ayat 112:

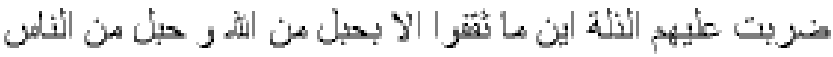

Bahkan dalam realitasnya, ibadah sosial yang nilai kemanfaatannya dirasakan oleh orang banyak diakui lebih utama daripada ibadah yang nilai kemanfaatannya hanya dirasakan oleh individu pelakunya. Berkaitan dengan hal ini, al- Suyūti mengatakan: ألمنَعني افضل من الثقلصر, artinya: "ibadah yang bermanfaat untuk orang banyak lebih utama daripada ibadah yang bermanfaat untuk diri sendiri". ${ }^{43}$ Pengertian yang bisa ditarik dari ungkapan ini adalah fardu kifäyah (kewajiban kolektif) lebih istimewa daripada fardu 'ayn (kewajiban individual) karena ia bisa menghilangkan kesulitan yang dialami umat. ${ }^{44}$

Imam al-Syatibi dalam stuktur maqāsid-nya telah memberikan alasan-alasan kenapa umat Islam perlu menjaga konsistensi pelaksanaan kewajiban individual dan kewajiban kolektif. Menurut al-Syatibi, kewajiban kifa'iyyah yang diperlawankan dengan kewajiban 'ayniyyah (kewajiban individual) merupakan kewajiban masyarakat yang mesti dilaksanakan dengan sebuah cara meskipun tidak setiap orang terlibat. Kewajiban kifa'iyyah bersifat mendasar dan penting karena itu ia termasuk dalam maqāsid al-Shari'ah. Kewajiban kifa'iyyah bersifat

${ }^{43}$ Jalāluddin 'Abdurrahman Ibn Abi Bakr al-Suyūti, al-Ashbāh wā al-Naz̧āir fí alFurū', (Beirūt, Dār al- Fikr, t.t), hlm. 100.

${ }^{44}$ Izzuddin menolak pemutlakan kaidah ini. Dia berkata bahwa kadang-kadang 'ibadah qasirah lebih utama daripada 'ibadah muta'diyyah seperti iman. Ibid. 
komplementer bagi kewajiban ayniyyah karena terlaksananya kewajiban kifa'iyyah akan memungkinkan terlaksananya kewajiban 'ayniyyah. Kewajiban kifa'iyyah bertujuan untuk merealisasikan kebaikan umum (al-maslahat al-'ammah). ${ }^{45}$

Berangkat dari pemikiran di atas, gagasan fikih sosial dibangun di atas sebuah kesadaran bahwa sudah saatnya umat Islam memperlakukan dua sisi ajaran yang mengatur hubungan individu dengan Tuhan ('ibadah mabdah) dan ajaran tentang hubungan individu dengan sesamanya (ibadah sosial) secara balance, integral, simultan, dan konsisten. ${ }^{46}$ Jika kesadaran ini muncul, maka tercipta pola keberagamaan yang komprehensif di kalangan umat Islam, yang ditandai dengan pribadi-pribadi yang salih (baik) dalam pandangan Allah dan dalam pandangan manusia.

Terminologi fikih sosial (al-figh al-ijtimä'i) sebenarnya penyempurna bagi fikih individu (al-fiqh al-infirädi). Jika al-fiqh al-infirädi lebih menekankan pada aspek ajaran tentang hubungan individu dengan Tuhan (ibadah mahdah) dan hubungan manusia dengan manusia dalam bentuk personal (bayna al-fard wa'l-fard), maka fikih sosial (al-figh alijtima'i) lebih menekankan kajiannya pada aspek ajaran tentang hubungan antar sesama manusia -antara individu dengan masyarakat dan masyarakat dengan masyarakat lainnya. ${ }^{47}$ Dengan pendekatan bahasa ini, fikih sosial dapat dipahami sebagai fikih yang berdimensi sosial atau fikih yang dibangun atas dasar hubungan antar individu atau kelompok di dalam masyarakat.

Gagasan fikih sosial dipahami sebagai upaya hukum (politik hukum) fikih tradisional dalam konteks transformasi sosial, sebuah ikhtiar tentang bagaimana mengaplikasikan dan mengharmonikan ajaran-ajaran fikih dengan persoalan-persoalan yang muncul dan berkembang. Pemaknaan ini dengan sendirinva memasukkan segala

${ }^{45}$ Abi Isḥaq Ibrahìm al-Syatibi, al-Muwāfaqāt fi Ușül al-Aḅkēm, Juz II, hlm. 177-

${ }^{46}$ Klasifikasi fikih klasik biasanya meliputi bidang 'ibadah, mu'amalah, munakahah, dan jinayah atau qada'. Dari sini dipaparkan cabang-cabang pengembangan, seperi 'ibadah mahdah dan ghairu mahdah, mu'amalah mäliyah iqtișadiyah, jināyah siyasah dan, fiqh al-mar'ah.

${ }^{47}$ Mahsun Fuad, Hukum Islam Indonesia, hlm. 109. 
dimensi ajaran fikih, baik perspektif individu (a1-infirädi) maupun sosial (al-ijtimái ), ke dalam wacana fikih sosial. Dalam hal ini, fikih Sosial mengandaikan bahwa antara kedua cabang fikih ini tidak dapat dipisahkan, akan tetapi se-baliknya, keduanya justru saling mengukuhkan dalam rangka ikut membentuk civilized makna ajaran Islam, sebagai cita cita akhir politik hukum Islam (tafqīh, proses menjalankan fikih).

\section{Penutup}

Fikih sudah sepatutnya bersifat emansipatoris terhadap problem sosial-kemasyarakatan. Dengan karakteristik ini, fikih sosial mengajarkan untuk meningkatkan kepekaan sosial, menggairahkan kegiatan sosial/ibadah sosial sebagai buah dari pengamalan fard 'ayn, pentingnya membangun kerjasama/harmonisitas di antara sesama dan sebaliknya mengikis egoisme kelompok, fanatisme golongan (ta'așbiy-yah), serta yang kalah penting, perlunya umat Islam mendayagunakan kekuatan rasionalitas dalam memahami agama dan menyikapi kehidupan.

Corak fikih seperti ini sejalan dengan prinsip dasar Islam yang sebenarnya menekankan dimensi kesalehan sosial sebagai konsekuensi dan implementasi dari kesalehan individual-vertikalistik. Watak dasar ajaran Islam yang peka terhadap dimensi sosial bisa dicermati dari perhatiannya terhadap masalah-masalah sosial-kemanusiaan. Tematema sentral yang bersinggungan dengan upaya penanganan masalahmasalah riil kemanusiaan cukup banyak menghiasi kosa kata al-Qur'an seperti penanganan yatim piatu, kaum lemah, dan pengentasan kemiskinan (al-Mà'ūn: 1-7), pencegahan kerusakan lingkungan hidup (alRūm: 11), penegakan hak asasi manusia dan prinsip egaliter (Āli 'Imrān: 159), pengembangan solidaritas sosial (al-Māidah: 2), dan lain-lain.

Dengan demikian, keimanan kepada Tuhan tidak hanya dibuktikan dengan menyembahnya tetapi juga harus diwujudkan dalam bentuk sifat kedermawanan terhadap orang lemah, khususnya fakir miskin dan anak yatim (Q.S al-Duha 9-11). Al- Qur'an mengumpamakan sekelompok orang yang memungut hasil kebun tanpa memperkenankan orang-orang miskin memperoleh bagian dari kebun itu dengan istilah "kebun yang sirna" (Q.S al-Qalam 17-33). Al-Qur'an juga mengecam sikap orang-orang yang mengumpulkan kekayaan tapi 
bersifat kikir (al-Humazah: 1-4) dan dengan tegas membedakan ganjaran antara orang kikir dengan orang dermawan (Q.S al-Layl: 5-9). Masih banyak ayat-ayat al-Qur'an lainnya yang mengecam sikap kikir dan sebaliknya menganjurkan agar bersikap dermawan khususnya kepada kaum lemah dan tertindas. ${ }^{48}$

Bisa dikatakan, ajaran Islam menjadikan ibadah yang mempunyai aspek sosial sebagai landasan membangun satu sistem yang mewujudkan kesejahteraan dunia dan akhirat. Dengan mengintegrasikan aspek sosial dalam beribadah berarti memberikan motivasi penting pada keimanan agar hidupnya betul-betul menonjolkan jiwa sosial.

Fungsi sosial dari ajaran Islam ini antara lain tampak jelas dalam ibadah zakat. Zakat bukanlah satu-satunya gambaran dari sistem yang tersedia dalam ajaran Islam dalam mewujudkan kesejahteraan umum bagi masyarakat. Namun, harus diakui bahwa zakat sangat penting kedudukannya dalam peningkatan kesejahteraan masyarakat karena merupakan titik sentral dari sistem tersebut. ${ }^{49}$

Pemanfaatan dana zakat yang dijabarkan dalam fikih perlu mempertimbangkan faktor-faktor pemerataan (al-tamim) dan penyamaan (al-taswiyah). Di samping itu, yang tidak kalah penting harus mempertimbangkan kebutuhan riil penerima zakat, kemampuannya dalam memanfaatkan dana zakat untuk peningkatan kesejahteraan dan pembebasan diri dari kemelaratan sehingga pada gilirannya ia bisa menjadi pembayar zakat, bukan lagi penerima zakat. Jika penerima zakat sudah biasa berdagang atau mengetahui ilmu perdagangan maka kepadanya diberikan modal usaha (dari hasil zakat) yang memungkinkannya memperoleh keuntungan yang dapat memenuhi kebutuhan pokoknya. Jika ia mem-punyai keterampilan pertukangan maka kepadanya diberikan per-kakas yang memungkinkan ia bekerja dalam bidang keterampilannya untuk mencukupi kebutuhan pokoknya. Jika ia tidak dapat berdagang atau tidak mempunyai suatu keterampilan dalam usaha tertentu maka kepadanya diberikan jaminan dengan jalan menanamkan modal, baik berupa harta yang tidak bergerak (tanah)

${ }^{48}$ Amin Abdullah, Studi Agama, Normativitas atau Historisitas?, cet. 1, (Yogyakarta: Pustaka Pelajar, 1999), hlm. 70.

${ }^{49}$ Ali Yafie, Menggagas Fiqh Sosial.., hlm. 233. 
Zubaedi

maupun harta yang berkembang seperti peternakan (masyi'ah), yang penghasilannya dapat mencukup kebutuhan pokok dalam hidupnya sehari-hari selama usia hidup rata-rata (kifāyat al-umr al-gälib) seseorang, yang diperkirakan 60 tahun dipotong usia yang sudah lewat. ${ }^{50}$

${ }^{50}$ Sayyid Bari Shata al-Dimyati, I 'anat al-Ṭalibin, (Kairo: Matba'ah al-Mashhad alḤasany, 1967), Juz. II, hlm. 189. 


\section{BIBLIOGRAFI}

Abdullah, M. Amin, Studi Agama Normativitas dan Historisitas?, cet. 1, Yogyakarta: Pustaka Pelajar, 1999.

Abdussomad, Muhyidin, Figh Tradisionalis, Malang: Pustaka Bayan, 2004.

Al-Syatibi, Abu Ishaq Ibrahim ibn Mūsa, al-Muwāafaqātfi Ușūl al-Sharì'ah, Kairo: Muṣțafā Muhammad, t.t.

Anwar, Syamsul, "Beberapa hal tentang Manhaj Tarjih dan Pemikiran Keislaman dalam Muhammadiyah", dalam Pengembangan Pemikiran Mubammadiyah, Yogyakarta: Majelis Tarjih dan Pengembangan Pemikiran Islam PP Muhammadiyah dan LPPI UMY, 2000.

Baso, Ahmad, "Melawan Tekanan Agama: Wacana Baru Pemikiran Fiqih NU", dalam Wacana Baru Fiqih Sosial 70 Tahun KH. Ali Yafi, Bandung: Mizan, 1997.

Al-Dahlawi, Syah Waliyullāh, Huijatullāh al- Bālighah, Beirut: Dār alMa'rifah, t.t.

Esposito, John L, The Oxford Encyclopedia of The Modern Islamic World, New York: Oxford University Press, 1995.

Ismāîl, Muhammad Bakr, al-Fiqh al-Wädì min al- Kitāb wa'-Sunnah, Kairo: Dār al Manar, 1990.

Al-Jauziyyah, Ibn Qayyim, I'läm al-Muwaqqi'in 'an Rabb al-'̄Alamin. Mesir: Maktabat al-Tijāriyyah, 1955..

Khallāa, 'Abdul Wahhāb, 'Ilm Ușùl al-Fiqh, Kairo: Dakwah Islamiyah Shabāb al-Azhar, 1968.

Mạ̣maș̣ani, Subḥi, Falsafat al-Tashri' fi al-Islām, Beirut, al-Kashshāf, 1946.

Al-Qarḍawi, Yūsuf, Gerakan Islam antara Perbedan yang Diperbolebkan dan Perpecahan yang Dilarang, terj. Aunur Rafiq, cet. 1, Jakarta: Robbani Press, 1994.

Rahmat, Imdadun (ed.), Kritik Nalar Fiqih NU, Jakarta: Lakspesdam NU, 2002.

Schaft, J, An Introduction to Islamic Law, Oxford: Oxford University, 1964. 
Zubaedi

Soenarjo, RHA, Al-Qur'an dan Terjemabannya, Jakarta: Depag RI, 1971. Al-Shāfíi, Muhammad ibn Idris, al-Umm, Beirut: Dār al-Fikr, 1994. Al-Suyūti, Jalāl al-Dīn 'Abd al-Raḥmān ibn Abì Bakr, al-Ashbah wa'Naz̧äir fi al-Furū', Beirut : Dār al- Fikr, t.t.

Yafie, Ali, Menggagas Fiqh Sosial, Bandung: Mizan, 1995.

Zahrah, Muhammad Abu, Ușül al-Fiqh,. Kairo: Dār al-Fikr al-'Araby, 1958. 